\title{
ADSORPTION OF BOVINE SERUM ALBUMIN ON AMORPHOUS CALCIUM PHOSPHATE IN RINGER SOLUTION
}

\author{
YOSHIYUKI KOJIMA, TOMONORI HAYASHI, TAMOTSU YASUE \\ and YASUO ARAI \\ Department of Industrial Chemistry, Faculty of Science and Engineering, \\ Nihon University, 1-8, Kanda-Surugadai, Chiyoda-ku, Tokyo 101-8308, Japan
}

\begin{abstract}
The present study was made to investigate adsorption of bovine serum albumin (BSA) on hydroxyapatite (HAp) which was crystallized by dipping amorphous calcium phosphate (ACP) in Ringer solution having a composition similar to body fluid in vivo. Characterization of products was determined by means of X-ray diffraction, ion chromatography and ultraviolet spectrophotometry. When ACP was dipped for 48 hours in Ringer solution, maximum amount of BSA adsorbed on HAp prepared by crystallizing ACP was $190 \mathrm{mg} / \mathrm{g}$. Adsorption velocity till reaching to maximum amount of BSA adsorbed on HAp was speeded up by increasing concentration of BSA. The equilibrium amount of BSA adsorbed on HAp was $1.2 \mathrm{mg} / \mathrm{m}^{2}$. When ACP was dipped in Ringer solution, the largest quantity of BSA could be adsorbed to HAp crystallized in a short time.
\end{abstract}

\section{INTRODUCTION}

A bone was surrounded by cell liquid between the blood plasma and the interstitial fluid. $\mathrm{Ca}^{2+}$ required during the growth and body metabolism of the bone was supplied from the blood plasma. The compositions in the blood plasma consisted of components such as $91 \%$ water, $7 \%$ protein, $1 \%$ lipid and $0.9 \%$ inorganic substance. The inorganic substance was composed $\mathrm{Na}^{+}, \mathrm{Cl}^{-}$and a little $\mathrm{Ca}^{2+}$. Also, the compositions of protein were consisted of albumin containing $50 \sim 70 \%$ and globulin.

The authors regarded that fine amorphous calcium phosphate (ACP) having high activity should be easy to adsorb with organic compounds, reported that adsorption of succinic acid or glycine on ACP and stability of ACP adsorbed glycine in Ringer solution having a composition similar to body fluid in vivo ${ }^{1) \sim 3)}$. This report used BSA that characterization was done sufficiently in studying interaction of ACP or HAp and albumin. The reports in the past regarding to adsorption albumin on HAp, which was purposed using as filler for chromatograph, have been given much attention by various author $\mathrm{s}^{4) \sim 6)}$, but the study of adsorption BSA on HAp crystallized by dipping ACP in simulated body fluid was hardly found. The present study was made to investigate crystallization of ACP and adsorption of BSA on HAp in simulated body 
fluid which was added BSA into Ringer solution as substitute of blood plasma.

\section{EXPERIMENTAL}

\section{MATERIALS}

The reagents used for the synthesis of ACP were anhydrous calcium nitrate $\left(\mathrm{Ca}\left(\mathrm{NO}_{3}\right)_{2}\right)$, diammonium hydrogenphosphate $\left(\left(\mathrm{NH}_{4}\right)_{2} \mathrm{HPO}_{4}\right)$ and aqueous ammonia $\left(\mathrm{NH}_{4} \mathrm{OH}\right)$, all supplied by Kanto Kagaku Co.Ltd. In addition, the regent grade BSA supplied by Nacalai Tesque Co.Ltd. Ringer solution consisted of 0.85 mass \% $\mathrm{NaCl}$, 0.02 mass $\% \mathrm{KCl}, 0.02$ mass $\% \mathrm{CaCl}_{2}$ and 0.002 mass $\% \mathrm{NaHCO}_{3}{ }^{7}$.

\section{EXPERIMENTAL METHOD}

ACP was synthesized by rapidly adding $\mathrm{Ca}\left(\mathrm{NO}_{3}\right)_{2}$ solution $\left(0.167 \mathrm{~mol} / \mathrm{dm}^{3}\right)$ into $\left(\mathrm{NH}_{4}\right)_{2} \mathrm{HPO}_{4}$ solution $\left(0.100 \mathrm{~mol} / \mathrm{dm}^{3}\right)$. In advance, in the $\left(\mathrm{NH}_{4}\right)_{2} \mathrm{HPO}_{4}$ solution was added with $\mathrm{NH}_{4} \mathrm{OH}$ solution to control $\mathrm{pH}$. Volume of the $\mathrm{Ca}\left(\mathrm{NO}_{3}\right)_{2}$ solution was set to the same as that of $\left(\mathrm{NH}_{4}\right)_{2} \mathrm{HPO}_{4}$ solution and the reaction temperature was held at $0{ }^{\circ} \mathrm{C}$. Gelatinous ACP obtained by mixing both solutions was filtered by a glass filter (G5). The gel was washed with aqueous $\mathrm{NH}_{4} \mathrm{OH}$ kept at the same $\mathrm{pH}$ as that used for the synthesis and acetone, treated with silica gel to remove moisture and finally dried in air to prepare ACP powder. ACP powder was dipped as suspension concentration of 1 mass \% in Ringer solution including 0 3 mass \% BSA and its suspension was held for $0 \sim 72$ hours in thermostat at $35^{\circ} \mathrm{C}$. ACP adsorbed BSA was prepared by filtering the suspension.

Characterization of the products was determined by means of X-ray diffraction, ion chromatography and ultraviolet spectrophotometry. The compositions of products were determined quantity of calcium by chemical analysis, quantity of phosphate ion by ion chromatography. The measurement of amount of albumin adsorbed on ACP or HAp was carried out by ultraviolet spectroscopic analysis. HAp in the suspension was sedimented with a centrifuge at $12000 \mathrm{rpm}$ for 15 minutes. Then the supernatant liquid was collected, concentration of albumin was determined by measuring the absorbance of $280 \mathrm{~nm}$ of the supernatant liquid.

\section{RESULTS AND DISCUSSION}




\section{ADSORPTION OF BSA IN CRYSTALLIZATION PROCESS OF ACP}

The fine ACP powder was spherical crystals with diameter of $0.06 \mu \mathrm{m}$ and its $\mathrm{Ca} / \mathrm{P}$ atomic ratio was 1.45 . Figure 1 illustrates effect of concentration of BSA on amount of BSA adsorbed on HAp which was crystallized by dipping ACP for 48 hours in Ringer solution. Amount of BSA adsorbed on HAp was successively increased till 1 mass \% concentration of BSA and then above 1 mass \% concentration of BSA was equilibrated at $190 \mathrm{mg} / \mathrm{g}$. Maximum amount of BSA adsorbed on HAp was $190 \mathrm{mg} / \mathrm{g}$ as very high value. However, the adsorption rate was differed by concentration of BSA although amount of adsorbed BSA was equilibrium.

From result of X-ray diffraction pattern of crystallization process of ACP in Ringer solution including different concentrations of BSA, crystallization of ACP to HAp began from 1 hour after dipping in 1 mass \% concéntration of BSA and the crystallization was finished within 3 hours. Crystallization of ACP in 3 mass \% concentration of BSA was delayed as

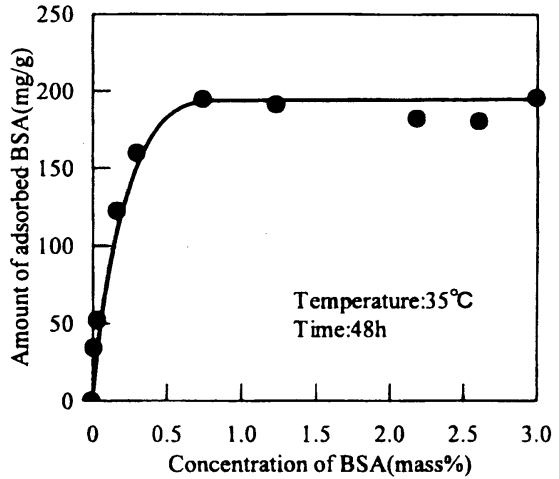

FIGURE 1, Effect of concentraition of BSA on amount of BSA adsorbed on HAp.

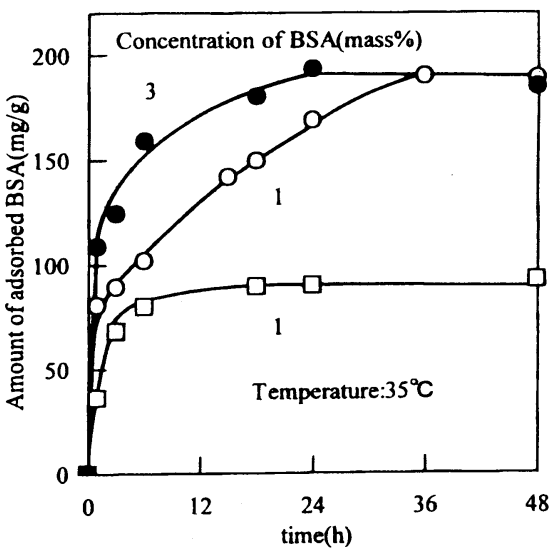

FIGURE 2. Effect of time on amount of BSA adsorbed on ACP Dipping solution, $\bigcirc, \bigcirc:$ Ringer solution, $\square:$ Water reaching to maximum amount of BSA adsorbed on HAp was $3.9 \mathrm{mg} / \mathrm{g} / \mathrm{h}$. On the other hand, in the case of 1 mass \% concentration of 
BSA, crystallization rate of ACP to HAp was fast as compared with that of 3 mass \% concentration of BSA and maximum amount of BSA adsorbed on ACP was only about $80 \mathrm{mg} / \mathrm{g}$. Time till reaching to maximum amount of adsorbed BSA was necessitated for 36 hours. Adsorption velocity of BSA on ACP was $80 \mathrm{mg} / \mathrm{g} / \mathrm{h}$, that of BSA on HAp was $3.1 \mathrm{mg} / \mathrm{g} / \mathrm{h}$. In other wards, the velocity was tended fast with increasing concentration of BSA. However, maximum amount of BSA adsorbed on HAp in water was $90 \mathrm{mg} / \mathrm{g}$. Above the result, amount of BSA adsorbed on HAp was increased by use of Ringer solution with $\mathrm{Na}^{+}$or $\mathrm{Ca}^{2+8)}$. The content of $\mathrm{Na}^{+}$in HAp absorbed BSA was slightly about 0.2 mass $\%$.

\section{ADSORPTION ABILITY OF BSA ON ACP OR HAP}

Figure 3 illustrates change in $\mathrm{Ca} / \mathrm{P}$ atomic ratio during crystallization process of $\mathrm{ACP}$ to HAp in Ringer solution. $\mathrm{Ca} / \mathrm{P}$ atomic ratio of HAp prepared by dipping ACP having $\mathrm{Ca} / \mathrm{P}$ atomic ratio of 1.45 in Ringer solution was increased with increasing time and then was levelled off 1.54 similar to bone of $\mathrm{Ca} / \mathrm{P}$ atomic ratio 1.55 above for 18 hours. The specific surface area of HAp adsorbed BSA was $160 \mathrm{~m}^{2} / \mathrm{g}$ and exceedingly fines HAp was confirmed to form.

Equilibrium amount of BSA adsorbed on HAp was calculated by dividing largest quantity of BSA adsorbed on HAp with specific surface area. Figure 4 illustrates adsorption isotherm of BSA on HAp. The adsorption isotherm of BSA on HAp was Langmuir type. Because the adsorption isotherm was equilibrated above 1 mass $\%$ concentration of BSA, the equilibrium value was estimated to be $1.2 \mathrm{mg} / \mathrm{m}^{2}$ by assuming the face-on adsorption of globular albumin molecules.

Elution of BSA adsorbed on HAp in Ringer solution was hardly detected. This was

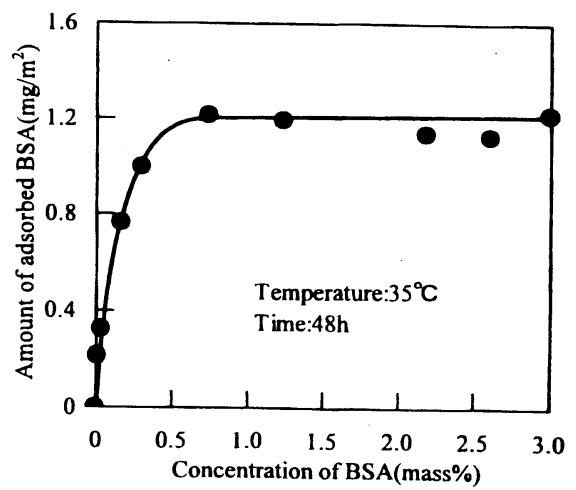

FIGURE 4. Adsorption isotherm for BSA on HAp. caused that carboxyl group in albumin was 
connected firmly with $\mathrm{Ca}^{2+}$ of HAp surface.

Table 1 shows the adsorption ability of BSA on ACP or HAp. Adsorption of BSA on ACP or HAp in present study was characterized that amount of adsorbed BSA was plenty. Maximum amount of BSA adsorbed on HAp was to be 4 times as compared with that of HAp for chromatography. This was because of high specific surface area of HAp. Namely, when ACP was dipped in Ringer solution, the largest quantity of BSA could be adsorbed to the HAp crystallized in a short time.

TABLE 1. Adsorption ability of BSA on ACP or HAp .

\begin{tabular}{|c|c|c|c|c|c|c|}
\hline & $\begin{array}{l}\text { Concentration } \\
\text { of BSA } \\
\text { (mass } \%)\end{array}$ & $\begin{array}{l}\text { Time } \\
\text { (h) }\end{array}$ & $\begin{array}{l}\text { Maximum amount } \\
\text { of adsorbed BSA } \\
(\mathrm{mg} / \mathrm{g})\end{array}$ & $\begin{array}{l}\text { Adsorption } \\
\text { velocity } \\
(\mathrm{mg} / \mathrm{g} / \mathrm{h})\end{array}$ & $\begin{array}{l}\text { Equilibrium amount } \\
\text { of adsorbed BSA } \\
\left(\mathrm{mg} / \mathrm{m}^{2}\right)\end{array}$ & $\begin{array}{l}\text { Specific } \\
\text { surface area } \\
\left(\mathrm{mg} / \mathrm{m}^{2}\right)\end{array}$ \\
\hline \multirow{2}{*}{$\mathrm{ACP}$} & $1.0(\mathrm{R})$ & 1 & 80 & 80 & - & 70 \\
\hline & $3.0(\mathrm{R})$ & 3 & 120 & 40 & - & 70 \\
\hline \multirow{2}{*}{ HAp } & $1.0(\mathrm{R})$ & 36 & 190 & 3.1 & 1.2 & 160 \\
\hline & $3.0(\mathrm{R})$ & 18 & 190 & 3.9 & 1.2 & 160 \\
\hline $\begin{array}{l}\text { Hap (for } \\
\text { chromatograph) }\end{array}$ & $1.0(\mathrm{R})$ & 24 & 40 & 1.7 & 1.1 & 36 \\
\hline ACP & $1.0(\mathrm{~W})$ & 1 & 35 & 35 & - & 70 \\
\hline HAp & $1.0(\mathrm{~W})$ & 12 & 90 & 4.6 & 0.6 & 150 \\
\hline
\end{tabular}

R:Ringer solution, W:Water

\section{REFERENCES}

1) T.Yasue, K.Masuda, Y.Kojima and Y.Arai, J.Ceram.Soc.Jpn., 102,1122(1994).

2) Y.Kojima, Y.Yamamoto, T.Yasue and Y.Arai, Phosphorus Res.Bull., 5, 59(1995).

3) Y.Kojima, T.Yasue and Y.Arai, Phosphorus Res.Bull., $\underline{6}, 313(1996)$.

4) T.Akazawa, N.Utida and K.Katsuse, Rep. Hokkaido Indust.Res.Insti., No.293,25(1994).

5) K.Kandori, M.Saito, H.Saito, A.Yasukawa and T.Ishikawa, Colloids Surf.:B, $\underline{5}, 225(1995)$.

6) M.J.Gorbunoff and S.N.Timasheff, Anal.Biochem., 136,440(1984).

7) J.Suwanprateeb, K.E.Tanner, S.Turner, W.Bonfield, J.Mater.Sci.,ㅁ,469(1997).

8) T.H.Diana, R.C.H.Wassell and E.Graham, Biomater., 16, 697(1995). 